Acta Universitatis Nicolai Copernici • Pedagogika XLI/1/2021

Nauki Humanistyczno-Społeczne • Zeszyt 453

DOI: http://dx.doi.org/10.12775/AUNC_PED.2021.009

Katarzyna Jadach

Uniwersytet im. Adama Mickiewicza w Poznaniu

ORCID: 0000-0002-4875-6558

\title{
WYCHOWANIE I KIEROWANIE
}

W WARUNKACH PIECZY ZASTĘPCZEJ -

ANALIZA STATUSU PRAWNEGO PODMIOTÓW

ZAANGAŻOWANYCH W EDUKACJĘ DZIECKA

RODZICÓW Z OGRANICZONĄ WŁADZĄ RODZICIELSKĄ

Upbringing and Guiding a Child Taken

Into Foster Custody - the Analysis of the Legal Status

of Entities Involved in the Education of the Child

of Parents with Restricted Parental Authority

\section{Streszczenie}

W niniejszym opracowaniu podjęto rozważania nad problemem relacji w układzie rodzice - wychowankowie pieczy zastępczej będący uczniami środowisko zastępcze - placówka oświatowa w sytuacji ingerencji sądu rodzinnego we władzę rodzicielską w postaci jej ograniczenia z uwagi na zagrożone dobro dziecka. Postawiono następujące pytanie badawcze: jak kształtuje się status prawny podmiotów zaangażowanych w edukację dziecka? Celem jego rozstrzygnięcia dokonano analizy dogmatyczno-prawnej, uwzględniając przede wszystkim przepisy prawa rodzinnego i oświatowego. Konstruowana na gruncie przywołanego w tekście art. 112.1 kodeksu rodzinnego i opiekuńczego koncepcja pieczy dzielonej i związany z nią rozdział atrybutów rodzi- 
cielskich nie zawsze pozwala na jednoznaczne ustalenie przynależności praw i obowiązków względem dziecka. W warunkach jego funkcjonowania w placówce oświatowej kategoryczny kompetencyjny podział rodzi wiele wątpliwości interpretacyjnych, co skłania do sformułowania postulatu obowiązku współdziałania rodziców z przedstawicielami pieczy zastępczej w obszarze wychowania i edukacji.

Słowa kluczowe: piecza zastępcza, system oświaty, piecza dzielona, obowiązki edukacyjne

\begin{abstract}
This study investigates the issues of the relationship between parents and foster children of school age, as well as between the foster environment and the educational institution, in a position of family court interference with restricting the parental authority due to the threatened welfare of the child. The following research question was posed: what is the established legal relationship of entities involved in the education of a child? In order to resolve it, considerations were made based on a dogmatic and legal analysis, with regard to family and educational legal regulations. The concept of shared custody and the separation of parental right were examined on the basis of the article 112.1 of The Family and Guardianship Code. Based on that analysis, it is concluded that it is not always unambiguous to determine the legal rights and obligations with regard to the child. Furthermore, the resolute division of competences raises many doubts. In conclusion, it is necessary for the parents and the foster care representatives to cooperate in order to maintain child's upbringing and education.
\end{abstract}

Ke y w o r d s : foster care, education system, shared custody, educational duties

\title{
Wprowadzenie
}

Towoczesne państwo podejmuje funkcje socjalne w ramach za1 dań opiekuńczych realizowanych zgodnie z założeniami przyjętej polityki rodzinnej. W przypadku państwa polskiego zobowiązanie do uwzględnienia przez władze publiczne dobra rodziny w kształtowa- 
niu rzeczywistości społeczno-gospodarczej wyrażono w art. 71 ust. 1 Konstytucji RP. Jednym z przykładów świadczenia tak ukierunkowanych usług społecznych jest system pieczy zastępczej. Uwzględnia on konstytucyjne gwarancje autonomii rodziny, umożliwiając jej racjonalne wspieranie do momentu, gdy osiągnie ona stan zdolności do samodzielnego realizowania potrzeb wychowawczych i opiekuńczych dzieci. W swojej najgłębszej warstwie aktywność państwa ma na celu prewencję, a więc zapobieganie osłabieniu więzi rodzinnych i zanikowi poczucia odpowiedzialności rodziny za los biskich. Powstaje jednak pytanie, czy otoczenie społeczne i formalne uwarunkowania funkcjonowania poszczególnych jego elementów sprzyjają realizacji założeń dotyczących upodmiotowienia rodzin objętych pieczą zastępczą. Formułując problem bardziej szczegółowo, należy zapytać, czy w pracy z rodziną napotykającą na problemy w wypełnianiu swojej wychowawczo-opiekuńczej funkcji, opartej na systemie pieczy zastępczej, uwzględnia się jej obecność w życiu dziecka, prymat w procesie jego wychowywania oraz założenie powrotu dziecka do jego naturalnego środowiska? W niniejszym opracowaniu przedmiotem analizy w zarysowanym wyżej kontekście uczyniono system oświaty ${ }^{1}$.

Uzasadnieniem dla podjęcia rozważań nad edukacyjną sytuacją dziecka umieszczonego w pieczy zastępczej, statusem jego rodziców oraz podmiotów tej pieczy są m.in. wnioski wypływające $\mathrm{z}$ analizy statystyk, przedstawiających ilościowe aspekty funkcjonowania omawianej instytucji².

1 Opracowaniem, w którym w sposób kompleksowy i pogłębiony dokonano analizy statusu prawnego dziecka w związku z jego umieszczeniem w pieczy zastępczej, jest pozycja M. Andrzejewskiego, Sytuacja prawna wychowanka pieczy zastępczej, w: Status osób małoletnich - piecza zastępcza, kontakty, przysposobienie, red. M. Andrzejewski, Warszawa 2020.

2 Dane opracowano na podstawie materiałów znajdujących się na stronie https://www.gov.pl/web/rodzina/opieka-zastepcza-nad-dzieckiem (dostęp: 28.01.2021). Zaczerpnięte one zostały z corocznych sprawozdań Rady Ministrów publikowanych na stronie internetowej Ministerstwa Rodziny i Polityki Społecznej w związku z delegacją art. 189 ustawy z dnia 09.07.2011 r. o wspieraniu rodziny i systemie pieczy zastępczej. Przepis ten zobowiązuje Radę Ministrów do cyklicz- 


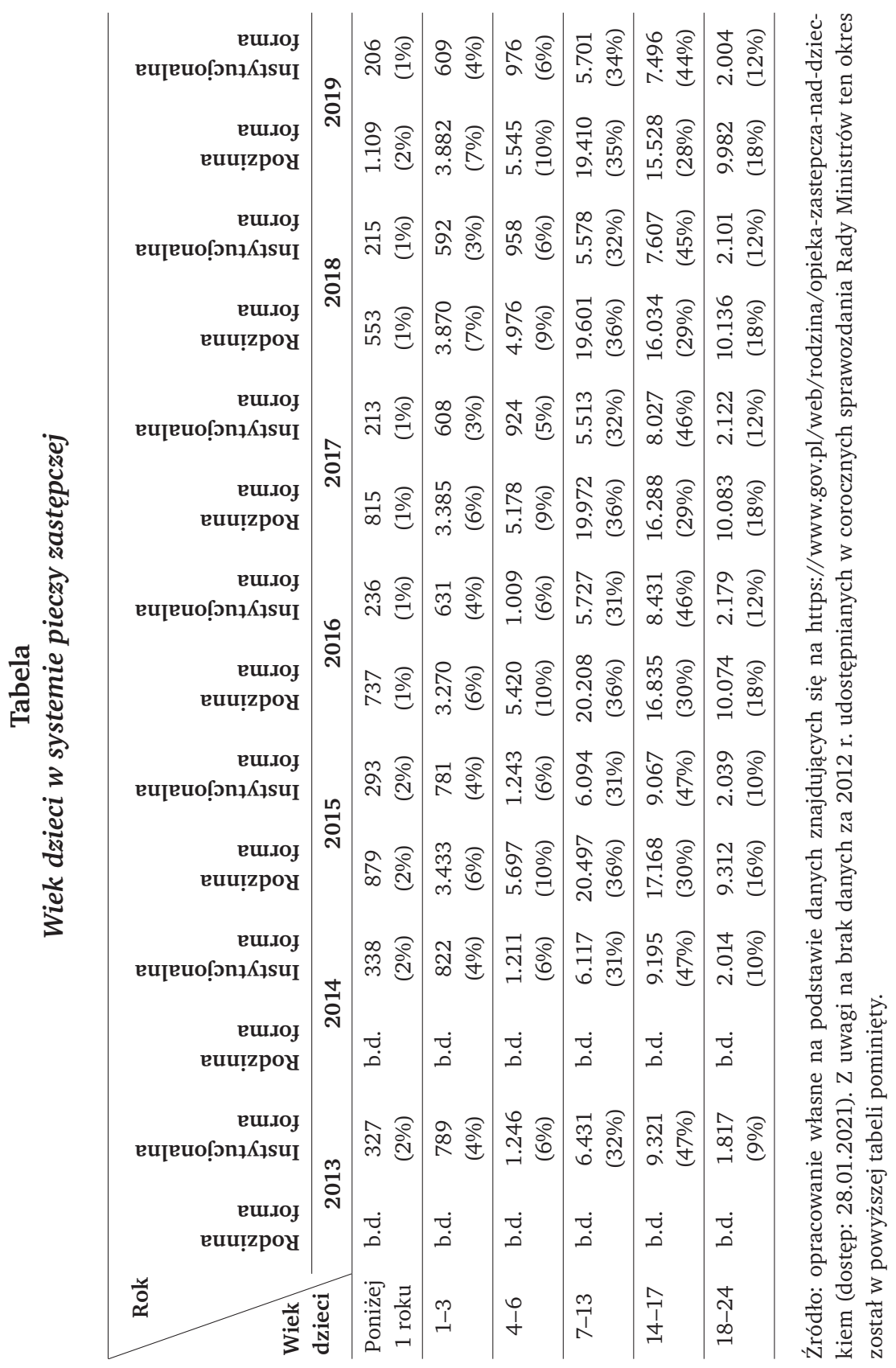


Wynika z nich, iż udział dzieci w pieczy zastępczej (wiek: 0-18 lat) w populacji dzieci do 18 r.ż. w okresie między 2012 r. a 2019 r. utrzymywał się na poziomie między 0,87 a 0,99 procent. Liczba dzieci umieszczonych w pieczy zastępczej wynosiła ponad 70.000 osób (2012 r.: 78.607; 2013 r.: 78.519; 2014 r.: 77.348; 2015 r.: 76.503; 2016 r.: 74.757; 2017 r.: 73.129; 2018 r.: 72.339; 2019 r.: 72.450), przy czym dynamika zmian w analizowanym okresie wskazuje na tendencję spadkową (między 2012 r. a 2018 r. jest to spadek o 8 procent), za wyjątkiem roku 2019, w którym nastąpił nieznaczny wzrost liczby umieszczeń dzieci w jednostkach pieczy zastępczej (o 111 przypadków w porównaniu z rokiem 2018). Dzieci w przeważającej liczbie przypadków umieszczane były w rodzinnych formach pieczy zastępczej (74 i więcej procent umieszczeń w każdym analizowanym roku w stosunku do umieszczeń $\mathrm{w}$ formach zinstytucjonalizowanych). Poniższa tabela przedstawia grupę dzieci objętych rodzinną i instytucjonalną pieczą zastępczą z podziałem na kategorie wiekowe: poniżej 1 r.ż., pomiędzy 1 a 3 r.ż., pomiędzy 4 a 6 r.ż., pomiędzy 7 a 13 r.ż., pomiędzy 14 a 17 r.ż. oraz pomiędzy 18 a 24 r.ż.

Z zaprezentowanych danych liczbowych wynika, iż: liczba dzieci w wieku 4-6 lat stanowiła w latach 2013-2019 9-10 procent umieszczeń $\mathrm{w}$ rodzinnych formach pieczy zastępczej, zaś 5-6 procent umieszczeń w formach instytucjonalnych. Dzieci młodsze (wiek poniżej 1 r.ż. oraz pomiędzy 1 a 3 r.ż.) stanowiły stosunkowo nieliczną grupę ogółu populacji wychowanków tego systemu. Najbardziej liczne były z kolei dwie grupy wiekowe i dotyczyło to obydwu form pieczy: dzieci pomiędzy 7 a 13 r.ż. (w pieczy rodzinnej udział procentowy tej grupy wynosił 35-36; zaś w pieczy instytucjonalnej - 31-34); oraz dzieci pomiędzy 14 a 17 r.ż. (odpowiednio: 28-30 i 31-34 procent). Duży odsetek stanowili również starsi wychowankowie, tzn. osoby, które przekroczyły 18 r.ż. W pieczy rodzinnej była to grupa 9-12 procent ogółu populacji dzieci objętych systemem, a w pieczy instytucjonalnej: 16-18 procent.

nego przedstawiania Sejmowi i Senatowi informacji o realizacji ustawy w roku poprzednim wraz z wnioskami o sposobie jej finansowania. 
Z zestawienia powyższych danych liczbowych wypływa wniosek, że większość wychowanków instytucji pieczy zastępczej (zarówno w formach rodzinnych, jak i zinstytucjonalizowanych) to dzieci w wieku przedszkolnym oraz szkolnym. Dzieci te, będąc członkami wspólnot rodzinnych, uzyskujących wsparcie w ramach systemu pieczy zastępczej, równocześnie funkcjonują w systemie oświaty: albo jako osoby, które mają prawo do edukacji przedszkolnej (wiek 3-5 lat); albo jako osoby objęte obowiązkiem rocznego przygotowania przedszkolnego (wiek 6 lat); albo jako osoby objęte obowiązkiem szkolnym i nauki (zasadniczo wiek 7-18 lat). Zmiany, jakie dokonały się w życiu rodzin, w szczególności zaś pojawienie się nowego podmiotu pieczy sprawowanej nad dzieckiem w postaci rodziny zastępczej bądź przedstawiciela pieczy zinstytucjonalizowanej, mogą w sposób zasadniczy wpływać na relacje w układzie rodzice - wychowankowie pieczy zastępczej będący uczniami - środowisko zastępcze - placówka oświatowa. Rodzi się w związku z tym pytanie: jak przepisy prawa rodzinnego oraz oświatowego odnoszą się do sytuacji sprawowania pieczy zastępczej nad dzieckiem przebywającym $\mathrm{w}$ placówce oświatowej? ${ }^{3}$

3 Przez pojęcie „placówka oświatowa” należy rozumieć przedszkola i szkoły (niezależnie od ich typów i rodzajów) jako podstawowe jednostki systemu oświaty. W art. 2 ustawy z dnia 14.12.2016 r. Prawo oświatowe (t.j. Dz.U. z 2021 r., poz. 1082) wskazano poszczególne elementy należące do systemu oświaty, jakimi są szkoły, przedszkola, placówki oświatowo-wychowawcze i inne szczegółowo wymienione podmioty; nie zdefiniowano jednak pojęcia „placówka oświatowa”. Z kolei w przepisach wykonawczych pojawia się pojęcie „placówka” i wykorzystywane jest ono do określenia innych niż szkoły i przedszkola jednostek systemów oświaty. Zdaniem autorki określenie „placówka oświatowa” nie jest tożsame z "placówką oświatowo-wychowawczą” czy „placówką artystyczną” i może stanowić wspólny zamiennik dla jednostek będących szkołami i przedszkolami, co dla jasności wywodu zawartego w niniejszym tekście ma zasadnicze znaczenie z uwagi na fakt, iż sytuacja wychowanków pieczy zastępczej, ich rodziców i przedstawicieli pieczy zastępczej analizowana jest z perspektywy funkcjonowania dziecka będącego zarówno w wieku przedszkolnym, jak i szkolnym. 


\section{Polski system wsparcia rodziny i pieczy zastępczej - ogólna charakterystyka}

Kształt polskiego systemu wsparcia rodziny i pieczy zastępczej determinują regulacje międzynarodowe ustanawiające standard ochrony praw dziecka umieszczonego poza rodziną. Kluczowe z perspektywy ochrony praw człowieka traktaty międzynarodowe ${ }^{4}$, określając rodzinę jako naturalną i podstawową komórkę społeczeństwa, której należy udzielać pomocy i wsparcia w opiece i wychowaniu dzieci, formułują zakaz arbitralnego wkraczania w życie prywatne jednostki i rodziny; akcentują obowiązek władzy państwowej poszanowania wolności rodziców do zapewnienia swym dzieciom wychowania i nauczania zgodnie z własnymi przekonaniami religijnymi i filozoficznymi. Na podstawie poszczególnych regulacji prawa międzynarodowego wywieść można dwie bardzo istotne zasady kształtujące relację pomiędzy państwem a rodziną, mianowicie: zasadę autonomii rodziny wobec wpływów państwa oraz zasadę prymatu rodziców w wychowaniu dzieci ${ }^{5}$. Prymat rodziny oraz służebna rola państwa najpełniej wybrzmiewa w Konwencji o prawach dziecka ${ }^{6}$, wyrażającej prawo dziecka do wychowania przez rodziców (prawo do życia w rodzinie) i ich nadrzędną rolę w zaspokajaniu jego potrzeb, co wiąże się z zakazem wyręczania rodziców w ich obowiązkach (zasada pomocniczości). Natomiast w zakresie funkcjonowania pieczy zastępczej, jako uniwersalny standard, wskazuje się prawo rodziny do pomocy ze strony społeczeństwa

4 Chodzi o: Międzynarodowy Pakt Praw Gospodarczych, Socjalnych i Kulturalnych z 19.12.1966 r. (art. 10 ust. 1), Międzynarodowy Pakt Praw Obywatelskich i Politycznych z 19.12.1966 r. (art. 18 ust. 4 i 23 ust. 1), Powszechną Deklarację Praw Człowieka z 10.12.1948 r. (art. XII i XXVI), Protokół nr 1 do Europejskiej Konwencji o Ochronie Praw Człowieka i Podstawowych Wolności z dnia 04.11.1950 r. (art. 2).

5 M. Andrzejewski, Piecza zastępcza, w: System Prawa Prywatnego. Tom 12. Prawo rodzinne i opiekuńcze, red. T. Smyczyński, Warszawa 2011, s. 407.

${ }^{6}$ Konwencja o prawach dziecka przyjęta przez Zgromadzenie Ogólne ONZ w dniu 20.11.1989 r. (zwłaszcza art. 7 ust. 1, art. 8 ust. 1, art. 18 ust. 2, art. 27 ust. 2-3). 
w sferze wychowania dzieci i obowiązek władz państwowych wprowadzania odpowiednich regulacji dotyczących przyjmowania dzieci potrzebujących opieki na wychowanie przez inną rodzinę przy równoczesnym uwzględnieniu naturalnych praw rodziców ${ }^{7}$. Podkreśla się ponadto tymczasowy charakter pieczy zastępczej, potrzebę wzajemnego kontaktu i współpracy rodziny dziecka z rodziną zastępczą oraz konieczność wprowadzenia nadzoru ze strony kompetentnej władzy celem ochrony dziecka umieszczonego w rodzinie zastępczej ${ }^{8}$.

Do powstania w Polsce systemu pieczy zastępczej, realizującego założenia aktów prawa międzynarodowego, przyczyniły się zmiany normatywne w krajowym porządku prawnym, zainicjowane w latach 90., a związane z reformami samorządową i systemu oświaty. Dotyczyły one przede wszystkim: przekazania zadań z zakresu pieczy zastępczej, $\mathrm{w}$ tym rodzin zastępczych, $\mathrm{z}$ resortu edukacji do resortu pracy i polityki społecznej; decentralizacji zadań publicznych w obszarze tworzenia systemu pieczy i prowadzenia rodzin zastępczych przez nowo utworzone powiaty; oparcia systemu wsparcia rodzin przeżywających trudności na zasadzie pomocniczości, zaś instytucji rodziny zastępczej - na zasadzie czasowości. Ówczesne zmiany normatywne ${ }^{9}$ ukie-

${ }^{7}$ Karta Praw Rodziny z 1982 r. (art. 3 lit. c i 4 lit. e), Wydawnictwo Sejmowe 2018. https://www.ore.edu.pl/2021/02/karta-praw-rodziny/ (dostęp: 15.02.2021). Dokument ten nie ma charakteru aktu normatywnego, jednak jest wypowiedzią prezentującą stanowisko Kościoła Katolickiego.

${ }^{8}$ Deklaracja Zgromadzenia Ogólnego ONZ w sprawie Zasad Społecznych i Prawnych dotyczących Ochrony i Dobrobytu Dzieci, ze szczególnym uwzględnieniem Opieki Zastępczej oraz Adopcji Krajowej i Międzynarodowej z 03.12.1986 r. Tłum. i oprac.: T. Jasudowicz, Prawa rodziny - prawa $w$ rodzinie $w$ świetle standardów międzynarodowych. Zbiór dokumentów, Toruń 1999, s. 113 i n.

${ }^{9} \mathrm{~W}$ tym kontekście wymienić należy przede wszystkim: ustawę z dnia 24.07.1998 r. o zmianie niektórych ustaw określających kompetencje organów administracji publicznej w związku z reformą ustrojową państwa, Dz.U. Nr 106, poz. 668; znowelizowaną ustawę z dnia 29.11 .1990 r. o pomocy społecznej, Dz.U. Nr 87, poz. 506 ze zm.; rozporządzenie Rady Ministrów z dnia 08.07.1999 r. w sprawie rodzin zastępczych, Dz.U. Nr 63, poz. 713 ze zm.; znowelizowaną ustawę z dnia 12.03.2004 r., Dz.U. Nr 64, poz. 593 ze zm.; znowelizowaną ustawę z dnia 09.06.2011 r. o wspieraniu rodziny i systemie pieczy zastępczej, Dz.U. Nr 149, poz. 887 ze zm. 
runkowane były na stworzenie spójnego systemu opieki nad dzieckiem $\mathrm{w}$ ramach pomocy społecznej opartego na pracy $\mathrm{z}$ rodziną $\mathrm{w}$ jej środowisku. Pomimo ewolucji stanu normatywnego, co stanowi cechę charakterystyczną uregulowań o charakterze administracyjnym ${ }^{10}$, odnotować można tendencje sprzyjające zarówno dzieciom pozbawionym opieki rodzicielskiej, rodzinom borykającym się z problemami wychowawczo-opiekuńczymi, jak i rodzinom zastępczym. Wiążą się one z respektowaniem podmiotowości głównych uczestników systemu pieczy zastępczej oraz priorytetowym traktowaniem dobra dziecka, przy respektowaniu innych chronionych prawem dóbr. Aktualnie w ramach stworzonego systemu pieczy akcentuje się wspieranie rodziny i przeciwdziałanie umieszczeniu dziecka poza jego naturalnym środowiskiem, a w sytuacji odłączenia - wspieranie rodziny w celu przygotowania jej do powrotu dziecka ${ }^{11}$.

\section{Piecza nad dzieckiem w systemie pieczy zastępczej}

Rodzicom zastępczym (ewentualnie przedstawicielom pieczy instytucjonalnej) przysługują w stosunku do dziecka określone prawa i obowiązki. To, jak szeroki jest ich zakres zależy od sposobu ingerencji sądu we władzę rodzicielską, a tym samym trybu umieszczenia dziecka w pieczy zastępczej. W związku z powyższym wyróżnia się sytuacje ${ }^{12}$ : 1) umieszczenie $\mathrm{w}$ rodzinie zastępczej na wniosek rodziców lub na podstawie

10 Do przywołanych w poprzedzającym przypisie ustaw wydanych zostało szereg aktów wykonawczych: rozporządzenie Rady Ministrów z dnia 26.09.2000 r. w sprawie rodzin zastępczych, Dz.U. Nr 83, poz. 939 ze zm.; rozporządzenie Rady Ministrów z dnia 29.09.2001 r. w sprawie rodzin zastępczych, Dz.U. Nr 120, poz. 1284; rozporządzenie Ministra Polityki Społecznej z dnia 18.10.2004 r. w sprawie rodzin zastępczych, Dz.U. Nr 233, poz. 2344 ze zm.; rozporządzenie Ministra Pracy i Polityki Społecznej z dnia 04.06.2010 r. w sprawie rodzin zastępczych, Dz.U. Nr 110, poz. 733.

11 S. Łakoma, Instytucja rodzin zastępczych $w$ prawie administracyjnym, Łódź 2014, s. 150-151.

12 M. Andrzejewski, Rodziny zastępcze - charakterystyka prawna, w: Rodziny zastępcze - problematyka prawna, red. M. Andrzejewski, Toruń 2006, s. 33. 
art. 100 Kodeksu rodzinnego i opiekuńczego ${ }^{13}$ (w skrócie: kro) (rodzice zachowują pełną władzę rodzicielską, a aktywność rodziny zastępczej sprowadza się do wykonywania pieczy bieżącej); 2) umieszczenie w rodzinie zastępczej następuje w związku z ograniczeniem władzy rodzicielskiej lub z zastosowaniem środka przewidzianego w ustawie o postępowaniu w sprawach nieletnich (uprawnienia i obowiązki względem dziecka rozdzielone są pomiędzy rodzicami oraz rodziną zastępczą, co reguluje art. $112.1 \mathrm{kro}$ ); 3) rodzicom zawieszono władzę rodzicielską lub ich jej pozbawiono, a nad dzieckiem ustanowiono opiekę prawną (opiekunami prawnymi dziecka umieszczonego w pieczy zastępczej są z reguły rodzice zastępczy); 4) rodzice dziecka zostali pozbawieni władzy rodzicielskiej i prawa do kontaktu z dzieckiem (w takim przypadku nad dzieckiem ustanawiana jest opieka prawna i uruchamiana może być procedura adopcyjna; pominąwszy kontrolę sądu, rodzina zastępcza swobodnie sprawuje nie tylko pieczę bieżącą, ale również wykonuje atrybuty pieczy nad osobą dziecka).

W niniejszych rozważaniach, w związku z podjęciem problemu formalnych uwarunkowań upodmiotowienia rodzin objętych systemem pieczy zastępczej oraz wynikających z nich relacji rodzice - wychowankowie pieczy zastępczej będący uczniami - środowisko zastępcze - placówka oświatowa, skoncentrowano się na sytuacji umieszczenia dziecka w rodzinie zastępczej (placówce opiekuńczej) w związku z ograniczeniem rodzicom władzy rodzicielskiej.

Z faktu ingerencji sądu opiekuńczego w zakres kompetencji rodziców wynika konieczność ustalenia, jakie atrybuty władzy rodzicielskiej pozostają przy rodzicach, a jakie przekazane są podmiotom pieczy zastępczej. Kwestię tę reguluje art. 112.1 kro. Wskazuje on, że: 1) wykonywanie bieżącej pieczy nad dzieckiem, jego wychowanie i reprezentowanie $\mathrm{w}$ tych sprawach (w szczególności w dochodzeniu świadczeń przeznaczonych na zaspokojenie jego potrzeb) należą do podmiotu pieczy zastępczej; 2) pozostałe obowiązki i prawa należą do rodziców dziecka; 3) sąd opiekuńczy może w postanowieniu inaczej określić zakres podziału tych atrybutów.

13 Ustawa z dnia 25.02.1964 r., t.j. Dz.U. z 2020 r. poz. 1359. 
Pierwszą konsekwencją unormowań powołanego wyżej przepisu jest wyodrębnienie z zakresu rodzicielskiego władztwa kategorii bieżącej pieczy i powierzenie jej wykonywania podmiotowi zastępczemu, co stanowi oczywiste rozwiązanie, bowiem dla prawidłowego wykonywania tego rodzaju pieczy niezbędny jest stały kontakt z dzieckiem. Piecza bieżąca obejmuje faktyczne starania o dziecko, których konieczność podjęcia wynika z typowych interakcji między dzieckiem a rodziną zastępczą ${ }^{14}$, zwłaszcza: gwarantowanie dziecku bezpieczeństwa, pozostawanie z dzieckiem we wspólności domowej, zapewnienie opieki lekarskiej, zapewnienie racjonalnego żywienia i odpowiedniej odzieży, kulturalnych warunków bytu, dbanie o systematyczne chodzenie do szkoły, pomoc w usamodzielnieniu się. Piecza bieżąca stanowi więc istotny element pieczy nad osobą dziecka. Podejmowana w jej obrębie aktywność rodziców zastępczych jest wyrazem troski o dziecko i sprowadza się do działań faktycznych, czyli oddziaływania na dziecko w trakcie zwykłych codziennych czynności życiowych ${ }^{15}$.

Druga wyodrębniona w art. 112.1 sfera aktywności przynależna podmiotom sprawującym pieczę zastępczą to wychowanie, przez które rozumie się całokształt zabiegów mających na celu zarówno ukształtowanie człowieka pod względem fizycznym, moralnym i umysłowym, jak i przygotowanie go do życia w społeczeństwie. Wychowywanie obejmuje oddziaływanie na dziecko w codziennych sytuacjach i często splata się z innym osobowymi elementami pieczy, zwłaszcza z troską o jego bezpieczeństwo oraz dokonywaniem wyborów, które mają wpływ na sytuację dziecka i przyjmowanie przezeń określonych postaw w przyszłości. Wychowania nie należy utożsamiać z przynależnym rodzicom atrybutem kierowania dzieckiem, rozumianym jako zarówno decydowanie o jego osobie, jak i za nie we wszystkich istotnych sprawach dotyczących wychowania, nauki, pracy, leczenia, miejsca pobytu czy wyjazdu za granicę ${ }^{16}$. Z drugiej strony oczywiste jest, iż zakresy znaczeniowe pojęć „wychowanie” oraz „kierowanie” zachodzą na siebie: decyzje po-

14 J. Strzebinczyk, Władza rodzicielska, w: Prawo rodzinne i opiekuńcze. System Prawa Prywatnego. Tom 12, red. T. Smyczyński, Warszawa 2011, s. 344.

15 M. Andrzejewski, Rodziny zastępcze..., s. 34.

16 M. Andrzejewski, Piecza zastępcza..., s. 438. 
dejmowane w sprawach dziecka dotyczą zarówno sfery wychowania, jak i wykraczają poza nią; z kolei wychowanie - w rozumieniu kodeksowym - obejmuje również prawo i obowiązek podejmowania ważnych decyzji ukierunkowujących proces rozwojowy dziecka ${ }^{17}$.

Z powyższego wynika, iż wychowanie dziecka umieszczonego $\mathrm{w}$ pieczy zastępczej obejmuje elementy kierowania pozostające $\mathrm{w}$ ścisłym związku z przebiegiem procesu wychowawczego ${ }^{18}$. W literaturze, uznając złożoność pojęcia wychowanie i potrzebę ustalenia zakresów kompetencyjnych rodziców i podmiotów pieczy zastępczej, proponuje się wyodrębnienie w ramach tego atrybutu - na podobieństwo pieczy nad osobą - „bieżącego wychowania dziecka”19. Podkreśla się, iż tego rodzaju działania wychowawcze nie obejmują codziennych niezbędnych zabiegów, lecz dotyczą podejmowania decyzji w kwestii wyboru zasadniczego kierunku kształcenia, a w takich sprawach nie sposób odmówić rodzicom decydującego głosu ${ }^{20}$. Pogląd ten bliski jest koncepcji rozdzielania zakresów znaczeniowych takich pojęć jak: „bieżąca piecza”, „wychowanie” i „kierowanie”21. Wyodrębniona jako samodzielna kategoria „kierowania dzieckiem”, interpretowana w związku z treścią art. $96 \S 1$ kro, polega na „ustalaniu «...» sytuacji prawnej i faktycznej dziecka, decydowaniu o jego ważniejszych sprawach oraz wytyczaniu jego «drogi życiowej» i kierunków rozwoju"22. Obejmuje ona rozmaite sfery życia dziecka, co sprawia, że jej charakterystyka opiera się na egzemplifikacji postaci rodzicielskiej aktywności. W doktrynie wskazuje się m.in.: określanie przez rodziców miejsca pobytu dziecka, odebranie go od osoby nieuprawnionej, czasowe powierzenie pie-

17 M. Safjan, Osamotnione dzieci. Rodziny zastępcze i rodzinne domy dziecka, Warszawa 1983, s. 167.

18 Tamże, s. 168.

19 M. Goettel, Kontrowersje wokół tak zwanej pieczy podzielonej nad małoletnim, „Acta Iuris Stetinensis”, 2014 nr 6, s. 409.

20 Tamże.

21 Taki pogląd reprezentują m.in.: M. Andrzejewski, Piecza zastępcza..., s. 438; J. Ignatowicz, M. Nazar, Prawo rodzinne, Warszawa 2012, s. 346; T. Sokołowski, w: Kodeks rodzinny i opiekuńczy. Komentarz, red. H. Dolecki, T. Sokołowski, Warszawa 2013, s. 650 i in.

22 M. Goettel, Kontrowersje wokół..., s. 412. 
czy nad dzieckiem innej osobie, regulowanie jego trybu życia, nadzór nad postępowaniem, decydowanie o uczestnictwie w działalności środowisk pozarodzinnych i partycypacji w różnych formach przejawiania kultu religijnego, oddziaływanie na sytuację zdrowotną dziecka, itp. ${ }^{23}$. Do podstawowego obszaru, w którym uruchamiany jest atrybut kierowania, należy edukacja. W tym kontekście należy poddać analizie odpowiednie regulacje z zakresu prawa oświatowego, odnosząc się do uregulowań ustawy z dnia 09 czerwca 2011 r. o wspieraniu rodziny i systemie pieczy zastępczej24 (w skrócie: WspRodzU).

\section{Sytuacja edukacyjna dziecka przebywającego w pieczy zastępczej}

Na gruncie prawa oświatowego terminem „rodzic” objęte zostały osoby, którym z racji biologicznych więzi z dzieckiem bądź prawnej więzi powstałej w wyniku przysposobienia przysługuje władza rodzicielska, a także osoby ustanowione przez sąd opiekuńczy opiekunami prawnymi dziecka oraz sprawujące pieczę zastępczą (art. 14 pkt 19 ustawy Prawo oświatowe, w skrócie: PrOświat). Podstawową cechę tak rozumianego statusu bycia rodzicem stanowi zakres obowiązków i uprawnień przysługujących osobom w związku z faktem sprawowania władzy rodzicielskiej, opieki prawnej lub pieczy zastępczej25. Nie jest konieczne, by rodzice dysponowali pełną władzą rodzicielską (może być ona ograniczona, np. poprzez ustanowienie nad rodziną nadzoru kuratora sądowego). Posiadanie przez rodziców (choćby ograniczonej) władzy rodzicielskiej stanowi warunek sine qua non ich funkcjonowania w warunkach placówki oświatowej, umożliwiając im podejmowanie rozmaitych czynności wynikających ze sprawowania pieczy i reprezentowania swojego dziecka.

$23 \mathrm{Na}$ temat składowych elementów atrybutu kierowania dzieckiem zob. m.in.: T. Sokołowski, w: Kodeks rodzinny i opiekuńczy..., s. 651-652.

24 T.j. Dz.U. z 2020 r., poz. 821 ze zm.

25 K. Jadach, Oświatowe konteksty wykonywania pieczy nad małoletnim, w: Dziecko-rodzice-państwo $w$ kontekście świadczeń zdrowotnych, edukacyjnych i przemocy domowej, red. M. Łączkowska-Porawska, Warszawa 2020, s. 58. 
Do zakresu znaczeniowego pojęcia „rodzic” przepisy oświatowe włączają również rodzinę zastępczą (ewentualnie przedstawiciela pieczy instytucjonalnej). Wynika to $\mathrm{z}$ istoty samej instytucji, uruchamianej w związku z koniecznością organizowania środowiska wychowawczego dziecka i reagowania na jego bieżące potrzeby. W przypadku zaistnienia w środowisku rodzinnym niesprzyjających warunków ustanowienie pieczy zastępczej, przejmującej część kompetencji rodziców wychowanka, umożliwia sprawującym pieczę zastępczą współpracę ze szkołą.

Piecza zastępcza ma, z jednej strony, zapewniać pracę z rodziną naturalną, z drugiej - zaspokajać potrzeby dziecka. Jej przedstawiciele obowiązani są zapewnić dziecku właściwe warunki bytowe, zdrowotne, a także edukacyjne czy kulturalno-rekreacyjne. Do ich zadań należy podejmowanie zabiegów służących przygotowaniu dziecka do godnego, samodzielnego i odpowiedzialnego życia oraz kształtowaniu umiejętności społecznych. W przepisach WspRodzU, regulujących osobowe formy pieczy zastępczej, wątek wychowawczego oddziaływania - obok obowiązku zapewnienia dziecku całodobowej opieki - został szczególnie uwypuklony. Wynika z nich, iż rodzina zastępcza w ramach bieżących wychowawczych zadań powinna zapewnić dziecku kształcenie, wyrównywać jego braki rozwojowe i szkolne, rozwijać uzdolnienia i zainteresowania, dbać o sferę społeczną i religijną.

Podejmowane $\mathrm{w}$ kierunku jak najpełniejszego zaspokojenia potrzeb wychowanka starania rodziców zastępczych mieszczą się w kategorii wychowania dziecka, o którym mowa w art. 112.1 kro. Pojemność tego pojęcia i jego wieloaspektowość w realiach oświatowych może jednak rodzić obawy o wkraczanie podmiotów pieczy zastępczej w ich codziennych zabiegach w sferę istotnych spraw i kierowania zarezerwowaną dla rodziców. Wynika to $\mathrm{z}$ faktu, iż obowiązek wychowania dziecka interpretowany na gruncie przepisów oświatowych dotyczy $\mathrm{w}$ zasadzie każdej sytuacji edukacyjnej, w tym m.in. obowiązków zapisania go do placówki, zapewnienia warunków do uczenia się, dopilnowania, by dziecko uczęszczało na zajęcia (art. 33 ust. 1, art. 40 ust. 1 i art. 40 ust. 2 PrOświat), prawa do członkostwa w radzie rodziców (art. 83 ust. 2 PrOświat) i radzie szkoły (art. 81 ust. 1 PrOświat), prawa złożenia wniosku o objęcie dziecka zajęciami świetlicowymi (art. 105 ust. 1 PrOświat), prawa złożenia wniosku o objęcie dziecka odpowiednią for- 
mą kształcenia z uwagi na treść orzeczenia o potrzebie kształcenia specjalnego (art. 127 ust. 14 PrOświat), prawa złożenia wniosku o wszczęcie postępowania rekrutacyjnego ${ }^{26}$ (art. 130 ust. 4 PrOświat). Rodzina zastępcza z uwagi na pobyt wychowanka w placówce oświatowej korzysta $\mathrm{z}$ tożsamych finansowych udogodnieńn ${ }^{27}$.

Podobnie przepisy regulujące problematykę pomocy psychologiczno-pedagogicznej odnoszą się do sytuacji, kiedy to istnieją podstawy dokonania pogłębionego rozpoznania potrzeb edukacyjnych lub objęcia określoną formą pomocy psychologiczno-pedagogicznej dziecka przebywającego w pieczy zastępczej. Z uprawnień rodzicielskich wynikających z unormowań dotyczących organizacji i udzielania tego typu pomocy, zarówno na terenie placówki oświatowej, jak i poradni psychologiczno-pedagogicznej korzystają rodzice sprawujący władzę rodzicielską nad dzieckiem, prawni opiekunowie dziecka oraz osoby (podmioty) sprawujące nad nim pieczę zastępczą ${ }^{28}$.

Warto również zauważyć, iż przepisy administracyjne odpowiedzialnymi za wypełnianie zadań wychowawczo-edukacyjnych czynią rodzinę zastępczą. Dokonuje się to poprzez nałożenie na przed-

26 Fakt objęcia kandydata pieczą zastępczą stanowi ustawowe - a więc niezależne od woli organu prowadzącego placówkę - kryterium w pierwszym etapie postępowania rekrutacyjnego, co stwarza większe szanse dostania się do wybranej szkoły w przypadku ograniczonej liczby miejsc. Zob. art. 131 ust. 2 PrOświat.

27 Przykładem takiego udogodnienia jest rządowy program wsparcia rodzin z dziećmi w ponoszeniu wydatków związanych z rozpoczęciem roku szkolnego, który przewiduje określonej wysokości świadczenia pieniężne dedykowane rodzicom, opiekunom faktycznym, opiekunom prawnym, rodzinom zastępczym, osobom prowadzącym rodzinne domy dziecka, dyrektorom placówek opiekuńczo-wychowawczych, dyrektorom regionalnych placówek opiekuńczo-terapeutycznych. Zob. § 4 rozporządzenia Rady Ministrów z dnia 30.05.2018 r. w sprawie szczegółowych warunków realizacji rządowego programu „Dobry Start”, Dz.U. z 2018 r. poz. 1061.

28 Literalnie do takiego kręgu podmiotów uprawnionych odnosi się $\S 6$ rozporządzenia Ministra Edukacji Narodowej z dnia 07.09.2017 r. w sprawie orzeczeń i opinii wydawanych przez zespoły orzekające działające w publicznych poradniach psychologiczno-pedagogicznych, Dz.U. 2017, poz. 1743; który wskazuje podmioty uprawnione do złożenia do poradni psychologiczno-pedagogicznej wniosku o wydanie orzeczenia lub opinii. 
stawicieli pieczy finansowych konsekwencji (grzywny) w sytuacji, gdy wychowanek nie realizuje obowiązków edukacyjnych (art. 42 ust. 1 PrOświat).

Wskazane wyżej przykłady angażowania rodziny zastępczej w sytuację edukacyjną wychowanka nie mogą jednak stanowić argument na rzecz marginalizowania rodziców w procesie wychowawczym i deprecjonowania ich roli w obszarze systemu oświaty. Skoro piecza zastępcza jest instytucją o charakterze pomocowym, zapewniającą pracę z rodziną, która ma umożliwić powrót dziecka do tej rodziny (art. 33 pkt 1 WspRodzU), do ustalonego na gruncie art. 112.1 kro podziału kompetencyjnego należy podejść w sposób gwarantujący rodzicom utrzymanie zasadniczego wpływu na losy edukacyjne ich dziecka, a więc oprzeć się w sytuacjach wątpliwych na wykładni zawężającej29. Taki kierunek interpretacji zgodny jest z konstytucyjną zasadą rodzicielskiego prymatu w wychowaniu dziecka, ułatwiając, w przypadku problemu z identyfikacją sprawy jako mieszczącej się bądź w kategorii „bieżącego wychowywania”, bądź też w zakresie „kierowania dzieckiem” (ewentualnie „kierowania wychowaniem dziecka”), wskazywanie ich jako osób uprawnionych, a zarazem zobowiązanych do podejmowania stosownych decyzji. Dotyczy to takich m.in. spraw, jak: wybór profilu kształcenia, w którego obrębie mieści się wybór określonego typu i rodzaju szkoły (profilu klasy w obrębie jednej placówki) i przedszkola, a także podejmowanie decyzji w sprawie zmiany placówki czy działania związane z organizacją pomocy psychologiczno-pedagogicznej, wynikające ze zdiagnozowania specjalnych potrzeb edukacyjnych dziecka

29 Por. J. Słyk, Komentarz do art. 112.1 krio, w: Kodeks rodzinny i opiekuńczy. Komentarz, red. K. Osajda, Warszawa 2020, Legalis/el. Potwierdzeniem takiej interpretacji relacji między rodziną a instytucjami tworzącymi system pieczy zastępczej może być również treść rekomendacji nr R(87)6 w sprawie rodzin zastępczych przyjętej przez Komitet Ministrów Rady Europy 20 marca 1987 r. Zawiera ona zasadę, która wyraża domniemanie obejmowania przez rodziców zastępczych odpowiedzialności rodzicielskiej jedynie w zakresie niezbędnym do wykonywania pieczy nad dzieckiem w sprawach codziennych i niecierpiących zwłoki (zasada nr 3). Por. opracowanie pod red. M. Safjan, Standardy prawne Rady Europy. Teksty i komentarze. Tom I. Prawo rodzinne, Instytut Wymiaru Sprawiedliwości, Warszawa 1994, s. 187. 
(w tym złożenie wniosku czy wyrażenie zgody, jaka jest wymagana od rodzica celem uruchomienia określonej formy pomocowej).

W tym kontekście pojawić się mogą obawy o zdolność rodziców do podejmowania decyzji w sposób uwzględniający najlepszy interes dziecka. Ograniczenie władzy rodzicielskiej oznacza przecież w wielu przypadkach niski poziom posiadanych przez nich kompetencji pedagogicznych $^{30}$. Problemem może być również brak kontaktu z nimi oraz brak z ich strony woli współpracowania z placówką oświatową. Takie postawy rodziców sygnalizują sędziowie i przedstawiciele jednostek powiatu $\mathrm{w}$ badaniach empirycznych ${ }^{31}$, rekomendując wprowadzenie reguły obligatoryjnego nałożenia na rodziców, w postanowieniu o umieszczeniu dziecka w pieczy zastępczej, obowiązku współpracy z asystentem rodziny (art. 109 § 2 pkt 1 kro), oraz, stosownie do indywidualnych okoliczności sprawy, innych obowiązków (np. udziału w warsztatach opie-

30 Problem ten zauważony jest w orzecznictwie oraz doktrynie prawniczej. Zob. m.in.: zalecenia kierunkowe w sprawie wzmożenia ochrony rodziny (uchwała z dnia 09.06.1976 r.), w których SN zaznaczył, że umieszczenie w rodzinie zastępczej lub placówce opiekuńczo-wychowawczej jest środkiem, który „powinien być stosowany dopiero wtedy, gdy inne zarządzenia nie dały pożądanego wyniku lub gdy ze względu na szczególne okoliczności sprawy można uznać, że takiego wyniku nie dadzą. Wydanie przeto takiej decyzji jest niezbędne, gdy środowisko rodzinne wywiera ujemny wpływ na wychowanie dziecka albo gdy rodzice nie są w stanie poradzić sobie z codziennymi problemami wychowawczymi"; sygn. akt III CZP 46/76, OSNCP 1976, Nr 9, poz. 184. W podobnym tonie wypowiedział się SN w postanowieniu z dnia 28.04.2000 r.: „Ograniczenie władzy rodzicielskiej nie stanowi środka represji w stosunku do rodziców, lecz jest środkiem ochrony zagrożonego dobra dziecka. Jego celem jest ochrona dziecka a równocześnie niesienie pomocy rodzicom, którzy z powodu trudności wychowawczych czy życiowych nie radzą sobie należycie z realizacją tego celu”; sygn. akt II CKN 452/00, Legalis 188107. Zob. też: postanowienie SN z dnia 13.09.2000 r., sygn. akt II CKN 1141/00, Legalis 188114. Na specyfikę zarządzenia o umieszczeniu dziecka w rodzinie zastępczej jako środka ostatecznego, uruchamianego w sytuacji gdy zachodzi konieczność odseparowania dziecka od rodziców przejawiających konsekwentnie negatywną postawę rodzicielską zwracają uwagę również sądy powszechne. Zob. wyrok SA w Białymstoku z dnia 28.10.2010 r., sygn. akt ACa 458/10, Legalis 298027.

31 A. Prusinowska-Marek, Praktyka sqdowa $w$ zakresie realizacji zasady tymczasowości pieczy zastępczej, „Prawo w działaniu”, 2019 nr 40, s. 66. 
kuńczo-wychowawczych). Ponadto w badaniach zwraca się uwagę na zasadność wprowadzenia w Ustawie o wspieraniu rodziny i systemie pieczy zastępczej zapisów o konieczności kontynuowania albo podjęcia pracy przez asystenta rodziny po zabraniu dziecka do pieczy zastępczej (regulujący tę kwestię art. 10 ust. 4 WspRodzU w swoim aktualnym brzmieniu tego nie gwarantuje) ${ }^{32}$. Należy również mieć na uwadze obowiązki nałożone na rodzinę zastępczą, których podstawowym zadaniem jest ochrona dobra dziecka. Prawidłowe sprawowanie pieczy nad wychowankiem oznacza ich aktywność w sytuacjach, gdy rodzice działają na szkodę dziecka (np. utrudniają inicjowanie, organizowanie czy wdrażanie wspierającej rozwój dziecka pracy pedagogicznej albo oddziałują na dziecko demoralizująco poprzez prezentowanie negatywnych postaw względem nauczycieli i szkolnych obowiązków). Wówczas zasadnym jest uruchomienie przez nich procedury sądowej dotyczącej modyfikacji zakresów kompetencji, obowiązków i uprawnień. Po zapoznaniu się z sytuacją dziecka sąd rozstrzyga, czy w okolicznościach danej sprawy podział zadań wynikający z art. $112.1 \S 1$ pkt 1 kro jest optymalny z punktu widzenia dobra dziecka ${ }^{33}$. Jeśli tak nie jest, zachodzi podstawa do sądowej interwencji w kierunku dalszego ograniczania, a nawet pozbawienia rodziców władzy rodzicielskiej (przesłanka nadużywania władzy rodzicielskiej lub rażącego zaniedbywania obowiązków względem dziecka z art. 111 kro ). Warto w tym miejscu podkreślić, iż zły wpływ na proces wychowania dziecka jego rodziców stanowi przesłankę uruchomienia wszystkich posiadających tę wiedzę podmiotów w kierunku wypełnienia przez nich obowiązku informacyjnego. Jest to bowiem okoliczność uzasadniająca wszczęcie z urzędu postępowania opiekuńczego (art. 572 § 1 kodeksu postępowania cywilnego).

32 Tamże, s. 73.

33 M. Andrzejewski, w: Kodeks rodzinny i opiekuńczy..., s. 746. Na temat orzekania w materii podziału kompetencji pomiędzy rodziców a rodzinę zastępczą na zasadach wyjątku od reguły wypowiedział się Sąd Najwyższy w uchwale z dnia 19.3.1976 r., III CZP 7/76, OSNPG 1976, Nr 6, poz. 25. Zob. też. J. Gajda, w: Kodeks rodzinny i opiekuńczy. Komentarz, red. K. Pietrzykowski, Warszawa 2018, s. 860. 


\section{Współdziałanie rodziców i podmiotów pieczy zastępczej w zakresie edukacji dziecka jako jego istotnej sprawie}

Jak słusznie zauważa się w doktrynie, na mocy postanowienia o umieszczeniu dziecka w pieczy zastępczej powstaje trójkąt, którego ramionami są relacje: dziecko - rodzice; dziecko - osoby lub instytucje sprawujące pieczę zastępczą; rodzice - osoby lub instytucje sprawujące pieczę zastępczą ${ }^{34}$. Osłabienie relacji pierwszego typu rodzi konieczność zainicjowania i utrzymywania relacji pozostałych. Ich istnienie ma służyć przeprowadzeniu działań wzmacniających kompetencje rodzicielskie, a w dalszej kolejności uzdrowieniu relacji rodzice - dziecko. Tym celom podporządkowane jest organizowane dla dziecka środowisko zastępcze.

W czasie funkcjonowania trójkąta dziecko staje się adresatem rozmaitych oddziaływań, podejmowanych zarówno przez rodziców, jak i osoby sprawujące nad nim zastępczą pieczę. Nie należy jednak tej sytuacji rozumieć jako dwuwładzy ${ }^{35}$, w której każdy podmiot posiadający kompetencje do wpływania na sytuację małoletniego w sposób dowolny i niezależny rozwija swoje uprawnienia. Przeciwnie, założeniem jest działanie wspólne i spójne, bo tylko takie stwarza szansę na osiągnięcie pozytywnych efektów wychowawczych ${ }^{36}$. Dla sytuacji wychowanka pieczy zastępczej będącego uczniem ów zgodny przekaz ma dodatkowo istotne znaczenie.

W przepisie prawa w pojęciu „wychowanie” nie sposób zakodować pedagogicznych kontekstów aktywności rodzicielskiej i dodatkowo przypisać jej wyłącznie jednym bądź drugim podmiotom. Rodzice i rodzina zastępcza są kompetentni w różnym zakresie, jednak dla osiągnięcia efektu objęcia dziecka całościową pieczą muszą działać wspólnie. Uznając więc złożoność procesu uczenia się i wychowywania, rodzącą niemożność wprowadzenia precyzyjnych podziałów obszarów kompetencyjnych rodziców i podmiotów pieczy zastępczej, za obowiązującą

34 M. Andrzejewski, Sytuacja prawna wychowanka..., s. 31.

35 Określenia tego użył M. Andrzejewski, Sytuacja prawna wychowanka..., s. 32 .

36 Tamże. 
linię postępowania przedstawicieli obu środowisk uznać należy współdziałanie $^{37}$. Przyjęcie takiej strategii stwarza realne szanse na realizację założeń, wynikających z zasady pomocniczości i tymczasowości pieczy zastępczej. Starania ukierunkowane na uwzględnienie prawa i obowiązku rodziców do ciągłej obecności w życiu szkolnym dziecka i ich partycypacji w procesach wychowania i nauczania zabezpieczają prawo dziecka do rodziny, a równocześnie stanowią ważny element pracy z rodziną dysfunkcyjną poprzez jej dowartościowanie i upodmiotowienie. Postawa nastawienia na współdziałanie w pewnym sensie chroni również autonomię rodziny, bowiem porozumienie osiągnięte przez rodziców i rodzinę zastępczą oddala wizję interwencji sądowej.

Osiągnięcie wzorca relacji na linii rodzice - podmioty pieczy zastępczej opartego na współdziałaniu wiąże się niejednokrotnie z ogromnym nakładem pracy, determinacją, cierpliwością, a niekiedy poświęceniem czasu czy rezygnacją z forsowania swojego zdania na temat rozwiązania najlepszego dla dziecka. Koszty te ponoszą rodzice zastępczy, a przynajmniej powinni być do tego przygotowani. Należy bowiem pamiętać, kto jest adresatem działań systemu wsparcia rodziny i jakie przeszkody w komunikacji mogą się pojawić. Funkcja służebna instytucji pieczy zastępczej względem rodzin dysfunkcyjnych oznacza gotowość do prowadzenia trudnego dialogu, w którym to od podmiotów pieczy zastęp-

37 W literaturze wysuwane są propozycje rozstrzygania ewentualnych konfliktów na linii rodzice - rodzina zastępcza w trybie art. $97 \S 2$ kro, jako przepisu, który można zastosować w drodze analogii. Tak m.in.: M. Safjan, Instytucja rodzin zastępczych..., s. 171; M. Goettel, Kontrowersje wokót..., s. 417. Wydaje się jednak, iż zwracanie się do sądu w sprawie istotnej dla dziecka, w której rodzice oraz rodzina zastępcza nie mogą dojść do porozumienia na tych samych zasadach, co zwaśnieni rodzice nie jest uzasadnione. Art. 97 § 2 umieszczony jest w oddziale dotyczącym władzy rodzicielskiej (oddział 2 rozdziału II poświęconego stosunkom rodzice - dzieci), natomiast instytucja pieczy zastępczej posiada w kodeksie rodzinnym i opiekuńczym odrębne dedykowane jej regulacje (oddział 2a zatytułowany „Piecza zastępcza”), w tym te odnoszące się wprost do stosunków między rodzicami a rodziną zastępczą (art.112.1 § 1-2). Por. J. Słyk, Komentarz do art. 112.1 krio, w: Kodeks rodzinny i opiekuńczy. Komentarz, red. K. Osajda, Warszawa 2020, Legalis/el (teza 14). Z uwagi na kodeksowe usytuowanie można wręcz zaproponować traktowanie art. 112.1 jako lex specialis w stosunku do mającego charakter ogólny art. 97. 
czej oczekuje się profesjonalizmu, otwartości, dojrzałości, umiejętności panowania nad emocjami, a w kontekście poruszanej tu problematyki - determinacji w zabiegach służących respektowaniu prawa dziecka do ciągłości wychowania oraz ochronie jego tożsamości. W związku z powyższym niepokoić może diagnoza Rzecznika Praw Dziecka, który podkreśla, że podmioty pieczy zastępczej często nie podejmują działań na rzecz powrotu dziecka do domu rodzinnego, np. w postaci ścisłej współpracy z rodziną czy przekazywania rodzicom dziecka wiedzy i umiejętności wychowawczych ${ }^{38}$. Z drugiej strony, nie sposób pominąć złożonych uwarunkowań funkcjonowania podmiotów pieczy zastępczej, w tym specyfiki ich zadań związanych z podjęciem się całkowitej opieki nad dziećmi pozbawionymi przejściowo lub trwale opieki rodzicielskiej, co wiąże się z wzięciem za nie pełnej odpowiedzialności, oczekiwaniem kompleksowego zaspokajania ich potrzeb i wspomaganiem rozwoju w różnych sferach ${ }^{39}$. Rodzicielstwo zastępcze stanowi więc ogromne wyzwanie z uwagi na samą jego istotę, formułowane względem niego postulaty i zakładane funkcje. Dodatkowo na sytuację

38 Informacja o działalności Rzecznika Praw Dziecka za rok 2017 oraz uwagi o stanie przestrzegania praw dziecka, Warszawa 2017, https://brpd.gov.pl/prawa-dziecka/ (dostęp: 27.01.2021 r.).

$39 \mathrm{~W}$ literaturze funkcjonuje odniesienie trudności roli rodzica zastępczego do realizowania postawy, roli czy też zawodu niemożliwego, czyli takiego, gdzie obowiązki wobec wartości mają taki charakter i wzajemne odniesienie do siebie, że wymagają uznania ich jednocześnie za konieczne do realizowania i niemożliwe do ostatecznego spełnienia. Zob. L. Witkowski, Filozoficzność $w$ kształceniu pedagogów jako otwieranie się na humanistykę, w: Colloquia Communia (2/75), Filozofia pedagogice. Pedagogika filozofii, Kraków 2003 (za:) M. Joachimowska, Rodzicielstwo zastępcze. Idea-Problemy-Analizy-Kompetencje, Bydgoszcz 2008, s. 62. Zdaniem autorki, ideał rodzica zastępczego ma charakter pedagogicznego ideału oksymoronicznego, niosąc dylematy etyczne, przyjmujące postać pytań: „Jak pogodzić wspieranie rodziny naturalnej dziecka z poczuciem, że ona dziecko skrzywdziła? Jak pomagać w utrzymaniu kontaktu dziecka z jego rodziną i jednocześnie zapewnić poczucie więzi w nowej rodzinie? Jak stabilizować sytuację dziecka w poczuciu tymczasowości i zastępstwa? Kiedy i jakie kontakty z rodziną naturalną utrzymywać, aby dziecko chronić? Jak zachować intymność życia rodzinnego jednocześnie pozwalając na ingerencję specjalistów z zespołu powołanego do spraw pomocy rodzinom podejmującym opiekę zastępczą?". 
osób zaangażowanych w pieczę zastępczą wpływają czynniki organizacyjne (organizacja systemu pieczy), zasoby finansowe, jakość współpracy z instytucjami czy rodziną dziecka. Z badań dotyczących wypalenia zawodowego osób sprawujących funkcje rodziny zastępczej wynika, iż najważniejszym problemem dotyczącym sytuacji rodzin zastępczych jest obszar dotyczący rodziny biologicznej, zwłaszcza zaś napięte stosunki i trudności z kontaktami ${ }^{40}$.

W staraniach na rzecz zaspokojenia potrzeb dziecka rodziny zastępcze mają prawo oczekiwać wsparcia ze strony podmiotów publicznych. Choć to rodzice zachowują prerogatywy w zakresie przedstawicielstwa osoby małoletniego, to jednak codzienny, systematyczny, bieżący kontakt z placówką oświatową podejmuje rodzina zastępcza, co stanowi ich obowiązek wynikający z treści art. $112.1 \S 1$ kro. W ramach starań o zaspokojenie rozwojowych potrzeb będą więc troszczyć się o funkcjonowanie swojego wychowanka w placówce oświatowej, reagować na postępy w nauce lub ich brak czy na zgłaszane przez pracowników placówki niepokojące zachowania dziecka. Będą też pokonywać bariery emocjonalne, społeczne i intelektualne utrudniające dziecku pobyt w placówce i realizację podstawy programowej oraz we współpracy z nauczycielem, szkolnym pedagogiem i psychologiem dążyć do kompensacji deficytów rozwojowych i włączać dziecko w działania z zakresu pomocy psychologiczno-pedagogicznej.

Rola placówki oświatowej jako podmiotu wchodzącego w skład systemu wspierania rodziny nie ogranicza się jednak do współdziałania z podmiotami pieczy zastępczej. Nauczyciele i kadra zarządzająca są zobowiązani do uwzględnienia praw rodziców ucznia i udzielania im wsparcia w realizowaniu funkcji wychowawczej (art. 1 pkt 2 PrOświat). Równocześnie gwarantuje się, iż system oświaty zapewnia „wychowanie rozumiane jako wspieranie dziecka w rozwoju ku pełnej dojrzałości w sferze fizycznej, emocjonalnej, intelektualnej, duchowej i społecznej" oraz „upowszechnianie wśród dzieci i młodzieży wiedzy o zasadach zrównoważonego rozwoju oraz kształtowanie postaw sprzyjających jego wdrażaniu w skali lokalnej, krajowej i globalnej" (art. 1 pkt 3

40 L. Młody, Wybrane korelaty wypalenia zawodowego rodziców zastępczych, „Problemy Opiekuńczo-Wychowawcze” 2018 nr 7, s. 40. 
i 15 PrOświat). Przyjmując założenie, iż edukacja stanowi fundament zrównoważonego społeczeństwa globalnego, akcentuje się, iż wychowanie i nauczanie służyć powinny ukształtowaniu człowieka otwartego poznawczo, emocjonalnie i etycznie, przy czym dotyczy to zarówno edukacji formalnej, jak i nieformalnej czy pozaformalnej ${ }^{41}$. Działania ukierunkowane na osiągnięcie zakładanych celów wychowawczych w stosunku do dziecka przebywającego w pieczy zastępczej wiążą się z koniecznością uwzględnienia szeregu trudności. Dzieci pochodzące z rodzin dysfunkcyjnych są często silnie straumatyzowane, doświadczają chaosu, braku przewidywalności, przemocy, przedmiotowego traktowania bądź etykietowania, w związku z czym wymagają szczególnych metod pracy ${ }^{42}$. Nauczyciel musi mieć na uwadze szereg specyficznych aspektów funkcjonowania takiego ucznia i w oparciu o holistyczną diagnozę współorganizować jego edukacyjną przestrzeń, która nie powinna ograniczać się wyłącznie do struktur tworzących edukację formalną. Ta bowiem, w dominującej większości przypadków dzieci przebywających w pieczy zastępczej, może okazać się nieadekwatna i niewystarczająca ${ }^{43}$. Poza gotowością do współpracy z koordynatorem i podmiotem pieczy zastępczej, służbą zdrowia czy przedstawicielami wymiaru sprawiedliwości, konieczna jest otwartość na wspieraną rodzinę, co wiąże się z respektowaniem gwarancji, takich jak: prawo do kontaktu z dzieckiem, a w jego ramach do informowania rodzica o sytuacji szkolnej dziecka; poszanowania autonomii w zakresie wyboru kierunku kształcenia czy kształtowania światopoglądu, decydowania o specyficznych formach aktywności. Może się również okazać, iż nauczyciel będzie się musiał zmierzyć z barierami o charakterze mentalnym, czyli przeszkodami utrudniającymi podejmowanie działań wspierających dziecko, wynikającymi z trudności akceptacji i zrozumienia pewnych kwestii przez rodziców. Zazwyczaj źródłem takiej bariery jest konflikt z rodziną zastępczą lub niezrozumienie przez rodzica specyficznych potrzeb dziecka, intencji pracowników oświaty bądź metodyki

41 A. Piekacz, Idee wychowania i edukacji dla zrównoważonego rozwoju w systemie pieczy zastępczej, „Zeszyty Naukowe Politechniki Śląskiej”, 2016 z. 95, s. 386.

42 Tamże, s. 387.

43 Tamże, s. 388. 
postępowania w związku z uruchamianą pomocą psychologiczno-pedagogiczną. Każda sytuacja rodząca obawy czy niezrozumienie ze strony rodzica powinna być mu tłumaczona, co jednak nie daje całkowitej pewności uniknięcia nieporozumień. W przypadku braku współdziałania pomiędzy rodzicami a rodziną zastępczą ich pojawienie się jest wysoce prawdopodobne. Próba ustalania $\mathrm{w}$ takich warunkach podmiotu kompetentnego $\mathrm{w}$ edukacyjnych sprawach dziecka jest z góry skazana na niepowodzenie. Poza tym dokonywanie tego typu ustaleń wykracza poza zakres uprawnień i obowiązków nie tylko zainteresowanego nauczyciela, wychowawcy czy nauczyciela specjalisty, ale również dyrektora. Jedynym sposobem rozwiązania konfliktu jest przekazanie sprawy sądowi opiekuńczemu, który na podstawie art. $112.1 \S 2$ kro dokonana bardziej optymalnego rozdziału obowiązków i uprawnień wynikających z władzy rodzicielskiej, mając na uwadze zaistniały spór. Nie można bowiem zapominać, iż zarówno w przypadku systemu oświaty, jak i systemu pieczy zastępczej wiodącą klauzulą wyznaczającą uniwersalny standard postępowania jest dobro dziecka, którego respektowanie wymaga zachowania należytej proporcji pomiędzy jego interesem a interesem rodziców, wymagającej niekiedy zabezpieczenia jak najlepszych interesów dziecka kosztem interesu dorosłych.

\section{Zakończenie}

Piecza zastępcza w Polsce jest elementem systemu wspierania rodzin borykających się z problemami wychowawczo-opiekuńczymi, a jej konstrukcja opiera się na uniwersalnych zasadach, jakie wywodzą się z prawa międzynarodowego, gwarancji konstytucyjnych, a przede wszystkim naturalnych praw, jakie przysługują jednostce i tworzonej przez nią wspólnocie rodzinnej. Praktyka funkcjonowania tej instytucji rodzi szereg pytań i wątpliwości, m.in. w kontekście kompetencji podmiotów pieczy zastępczej w obszarze edukacji wychowanków. Facylitujący charakter mogą w związku z tym mieć poniższe uogólnienia.

1. Realizacja prawa dziecka do roztoczenia nad nim pieczy zastępczej ma charakter służebny wobec nadrzędnego prawa dziecka do życia 
w rodzinie własnej ${ }^{44}$. Idei tej służy większość sądowych ingerencji we władzę rodzicielską ${ }^{45}$. Kluczowe znaczenie ma również pedagogiczna zasada planowania stałości w opiece, czyli zapewnienie stabilnego środowiska wychowawczego. Akcentuje ona uzupełniającą funkcję instytucji pieczy zastępczej, co tym samym nie oznacza zastępowania czy też marginalizowania rodziny. Z zasadą tą wiąże się „nakaz zapobiegania umieszczania dzieci poza rodziną, skracania okresu sprawowania pieczy zastępczej oraz utrzymywania przez dziecko więzi z rodzicami w każdej sytuacji, w której istnieją szanse reintegracji rodziny naturalnej"46. Dopiero w sytuacji niemożności osiągnięcia tego celu należy rozważyć objęcie rodziny systemem pieczy zastępczej ${ }^{47}$. Z powyższych względów praca z rodziną dysfunkcyjną powinna obejmować również zaangażowanie rodziców w działania wychowawcze adresowane do ich dziecka umieszczonego w pieczy zastępczej.

2. W układzie relacji rodzice - podmioty pieczy zastępczej, gdy rodzicom ograniczona została władza rodzicielska, zastosowanie ma art. 112.1 kro. Przepis ten stanowi normatywną podstawę sformułowania koncepcji pieczy dzielonej, ale również rozdziału atrybutów: pieczy z podziałem na „pieczę bieżącą” i pieczę nie mającą takiego charakteru oraz wychowania z podziałem na „bieżące wychowanie” oraz „czynności wychowawcze niemające charakteru bieżącego”; czy też kategorii „kierowania wychowaniem". Istnienie tego ostatniego pozaustawowego określenia rodzi pytanie, o jego szczegółową zawartość (elementy składowe). Zakres sfery kierowania wychowaniem dziecka jest otwarty i uzależniony

44 M. Andrzejewski, Rodziny zastępcze..., s. 122.

45 M. Andrzejewski, Ochrona praw dziecka $w$ rodzinie dysfunkcyjnej (dziecko-rodzina-państwo), Zakamycze 2003, s. 181.

46 M. Andrzejewski, Rodziny zastępcze..., s. 123. Działania podejmowane w myśl tej zasady mają zastosowanie w polskim systemie pomocy społecznej w obszarze pracy z rodziną, gdzie planowanie stałości sprowadza się do realizacji postulatu, by po odseparowaniu dziecka od rodziców kompetentne gremia socjalno-pedagogiczno-prawne możliwie prędko przyjęły plan pracy z dzieckiem i jego rodziną w celu doprowadzenia do stworzenia dziecku stabilnej sytuacji życiowej”, M. Andrzejewski, Ochrona praw dziecka..., s. 223-224.

47 J. Ignatowicz, M. Nazar, Prawo rodzinne, Warszawa 2012, s. 350. 
od właściwości samego dziecka (jego predyspozycji, uzdolnień, stopnia dojrzałości), w związku z tym nadmierna kazuistyka przywołująca poszczególne czynności składające się na wychowanie jest bezcelowa. Niemniej należy zauważyć, że w doktrynie ${ }^{48}$ wśród elementów kierowania wychowaniem wymienia się przede wszystkim działania dotyczące realizacji celów edukacyjnych (np. wyznaczanie czasu nauki, pracy, zabawy, kontrolowanie trybu życia, nadzorowanie sposobu spędzania czasu wolnego, decydowanie o wyborze placówki oświatowej, o uczęszczaniu dziecka na zajęcia pozalekcyjne, o pobieraniu nauki religii, o przynależności dziecka do organizacji młodzieżowej). W realiach funkcjonowania dziecka w systemie oświaty kategoryczny rozdział na czynności podejmowane w ramach bieżącego wychowania, czynności wychowawcze niemające charakteru bieżącego, czy też te stanowiące „kierowanie wychowaniem" jest trudny do zastosowania.

Kompromis zawarty w regulującym tę materię art. 112.1 kro ma gwarantować swoistą równowagę pomiędzy prawami rodziny zastępczej i rodziców, i prowadzi do wniosku, że w pewnych sprawach dotyczących dziecka umieszczonego w pieczy zastępczej konieczne jest zgodne działanie rodziców z przedstawicielami tejże pieczy ${ }^{49}$. Brak takiego porozumienia może zakłócać proces wychowawczy (poprzez brak jednoznacznego przekazu, niekonsekwencję, podważanie stanowiska drugiej strony), co uzasadnia aktywność sądu ukierunkowaną na wypracowanie rozwiązania akceptowanego przez obie strony, a w przypadku niemożności jego osiągnięcia - władczą modyfikację zakresów uprawnień i obowiązków obu stron (art. $112.1 \S 2$ ). Rodzice, którzy nie widzą potrzeby współpracy z sprawach dotyczących ich dziecka, muszą liczyć się z wydawaniem przez sąd kolejnych zarządzeń na gruncie art. 109 kro, a nawet - w wypadkach skrajnych - zastosowaniem instytucji pozbawienia władzy rodzicielskiej; z kolei sabotowanie praw rodzicielskich przez rodzinę zastępczą może doprowadzić do jej rozwiązania lub

48 J. Winiarz, Prawo rodzinne, Warszawa 1974, s. 191; M. Safjan, Instytucja rodzin zastępczych..., s. 170.

49 M. Andrzejewski, Rodziny zastępcze..., s. 169. 
wyciągnięcia konsekwencji pracowniczych w stosunku do osób zatrudnionych $\mathrm{w}$ formach instytucjonalnych ${ }^{50}$.

3. Celem ograniczenia potencjalnych konfliktów rozstrzyganych na gruncie postępowania sądowego, co rodzić może u dziecka problemy natury emocjonalnej (tzw. konflikt lojalności), poszczególne służby i przedstawiciele jednostek samorządowych powinni w ramach dostępnych im środków i narzędzi inicjować i podtrzymywać działania koncyliacyjne i mediacyjne celem stworzenia warunków do jak najbardziej efektywnej współpracy między rodzicami a podmiotami pieczy zastępczej. Z jednej strony, będzie to oznaczało pracę z rodziną dysfunkcyjną, np. prowadzoną przez asystenta rodziny czy kuratora sądowego, z drugiej - wsparcie dla rodzin zastępczych i placówek opiekuńczych, ukierunkowaną na przeciwdziałanie wypaleniu zawodowemu i zrozumienie istoty rodzicielstwa zastępczego, zwłaszcza zaś jego służebnej funkcji.

W działaniach na rzecz współdziałania nie można z pola widzenia tracić interesu dziecka. Jest ono w zasadzie zgodne $\mathrm{z}$ dobrem wspieranej rodziny, jednak niewykluczone są sytuacje, kiedy to konkretna decyzja wymaga poświęcenia interesu rodziców dla właściwego zabezpieczenia małoletniego. Polskie prawo przewiduje w takich przypadkach możliwość ustalania zakresów kompetencyjnych rodziców i podmiotów pieczy zastępczej poprzez zwiększenie uprawnień tych drugich kosztem odpowiednich uprawnień rodziców. Przyznanie rodzinie zastępczej dominującej pozycji w obszarze wychowania należy traktować jako wyjątkowe rozstrzygnięcie sądu ${ }^{51}$, konieczne do podjęcia w sytuacjach, gdy rodzice negatywnie oddziałują na proces wychowawczy. Dla oświatowego kontekstu tego procesu oznacza to wówczas jednoznaczne wskazanie podmiotu kierującego edukacją dziecka, a więc władnego w podejmowaniu decyzji o rodzaju placówki oświatowej, jej zmianie, wyborze dalszego kierunku kształcenia, uczestnictwie

50 M. Andrzejewski, Sytuacja prawna wychowanka..., s. 33.

51 Zdaniem E. Holewińskiej-Łapińskiej, ten sposób modyfikacji jest w praktyce bardziej prawdopodobny; glosa do uchwały SN z dnia 02.10.1991 r., III CZP 92/91, PiP 1992, Nr 2, s. 113. 
dziecka w wymianach czy stażach wymagających dłuższego wyjazdu, czy czasowym pobycie $\mathrm{w}$ internacie.

\section{Bibliografia:}

Andrzejewski, Marek. Ochrona praw dziecka $w$ rodzinie dysfunkcyjnej (dziecko - rodzina - państwo). Zakamycze: Kantor Wydawniczy Zakamycze, 2003.

Andrzejewski, Marek. „Rodziny zastępcze - charakterystyka prawna”. W: Rodziny zastępcze - problematyka prawna, red. Marek Andrzejewski, 19-59. Toruń: Wydawnictwo „Dom Organizatora”, 2006.

Andrzejewski Marek. „Piecza zastępcza”. W: System Prawa Prywatnego. Tom 12. Prawo rodzinne i opiekuńcze, red. Tadeusz Smyczyński, 387-488. Warszawa: Wydawnictwo C.H. Beck, Instytut Nauk Prawnych PAN. Warszawa, 2011.

Andrzejewski, Marek. „Sytuacja prawna wychowanka pieczy zastępczej”. W: Status osób małoletnich - piecza zastępcza, kontakty, przysposobienie, red. Marek Andrzejewski, 15-77. Warszawa: Wydawnictwo Instytut Nauk Prawnych PAN, 2020.

Gajda, Janusz, w: Kodeks rodzinny i opiekuńczy. Komentarz, red. Krzysztof Pietrzykowski, s. 859-862. Warszawa: Wydawnictwo C.H.Beck, 2018.

Goettel, Mieczysław. „Kontrowersje wokół tak zwanej pieczy podzielonej nad małoletnim". Acta Iuris Stetinensis 6 (2014): 401-427.

Jadach, Katarzyna. „Oświatowe konteksty wykonywania pieczy nad małoletnim". W: Dziecko-rodzice-państwo w kontekście świadczeń zdrowotnych, edukacyjnych i przemocy domowej, red. Małgorzata Łączkowska-Porawska, 47-89. Warszawa: Wydawnictwo INP PAN, 2020.

Joachimowska, Magdalena. Rodzicielstwo zastępcze. Idea-Problemy-Analizy-Kompetencje. Bydgoszcz: Wydawnictwo Uniwersytetu Kazimierza Wielkiego, 2008.

Łakoma, Sylwia. Instytucja rodzin zastępczych $w$ prawie administracyjnym. Łódź: Uniwersytet Łódzki, 2014.

Młody, Lidia. „Wybrane korelaty wypalenia zawodowego rodziców zastępczych". Problemy Opiekuńczo-Wychowawcze 7 (2018): 35-43. 
Piekacz, Anna. „Idee wychowania i edukacji dla zrównoważonego rozwoju w systemie pieczy zastępczej". Zeszyty Naukowe Politechniki Śląskiej 95 (2016): 383-396.

Prusinowska-Marek, Alina. „Praktyka sądowa w zakresie realizacji zasady tymczasowości pieczy zastępczej”. Prawo w działaniu 40 (2019): 43-78.

Safjan, Marek. Osamotnione dzieci. Rodziny zastępcze i rodzinne domy dziecka. Warszawa: Wydawnictwo Prawnicze, 1983.

Safjan, Marek. „Rekomendacja Nr R(87)6 w sprawie rodzin zastępczych (przyjęta przez Komitet Ministrów Rady Europy 20 marca 1987 r.). Komentarz". W: Standardy prawne Rady Europy. Teksty i komentarze. Tom I. Prawo rodzinne, red. Marek Safjan, s. 180-190. Warszawa: Instytut Wymiaru Sprawiedliwości, Wydawnictwo Oficyna Naukowa, 1994.

Słyk, Jerzy. „Komentarz do art. 112.1 krio”. W: Kodeks rodzinny i opiekuńczy. Komentarz, red. Konrad Osajda. Legalis/el., 2020.

Sokołowski, Tomasz, w: Kodeks rodzinny i opiekuńczy. Komentarz, red. Henryk Dolecki, Tomasz Sokołowski, 645-653. Warszawa: Wydawnictwo Wolters Kluwer Polska, 2013.

Strzebinczyk, Jerzy. „Władza rodzicielska”. W: Prawo rodzinne i opiekuńcze. System Prawa Prywatnego. Tom 12, red. Tadeusz Smyczyński. Warszawa: Wydawnictwo C.H.Beck, Instytut Nauk Prawnych PAN, 2011.

\section{Akty prawne:}

Konwencja o Prawach Dziecka przyjęta przez Zgromadzenie Ogólne ONZ w dniu 20 listopada 1989 r.

Ustawa z dnia 25 lutego 1964 r. Kodeks rodzinny i opiekuńczy, t.j. Dz.U. z 2020 r. poz. 1359.

Ustawa z dnia 09 czerwca 2011 r. o wspieraniu rodziny i systemie pieczy zastępczej, t.j. Dz.U. z 2020 r., poz. 821 ze zm.

Ustawa z dnia 14 grudnia 2016 r. Prawo oświatowe, t.j. Dz.U. z 2021 r., poz. 1082.

Rozporządzenie Ministra Edukacji Narodowej z dnia 07 września 2017 r. w sprawie orzeczeń i opinii wydawanych przez zespoły orzekające działające w publicznych poradniach psychologiczno-pedagogicznych, Dz.U. 2017, poz. 1743.

Rozporządzenie Rady Ministrów z dnia 30 maja 2018 r. w sprawie szczegółowych warunków realizacji rządowego programu „Dobry Start”, Dz.U. z 2018 r. poz. 1061. 
Strony internetowe:

https://www.gov.pl/web/rodzina/opieka-zastepcza-nad-dzieckiem. https://www.ore.edu.pl/2021/02/karta-praw-rodziny/. https://brpd.gov.pl/prawa-dziecka/. 